\title{
325
}

\section{APR 71964}

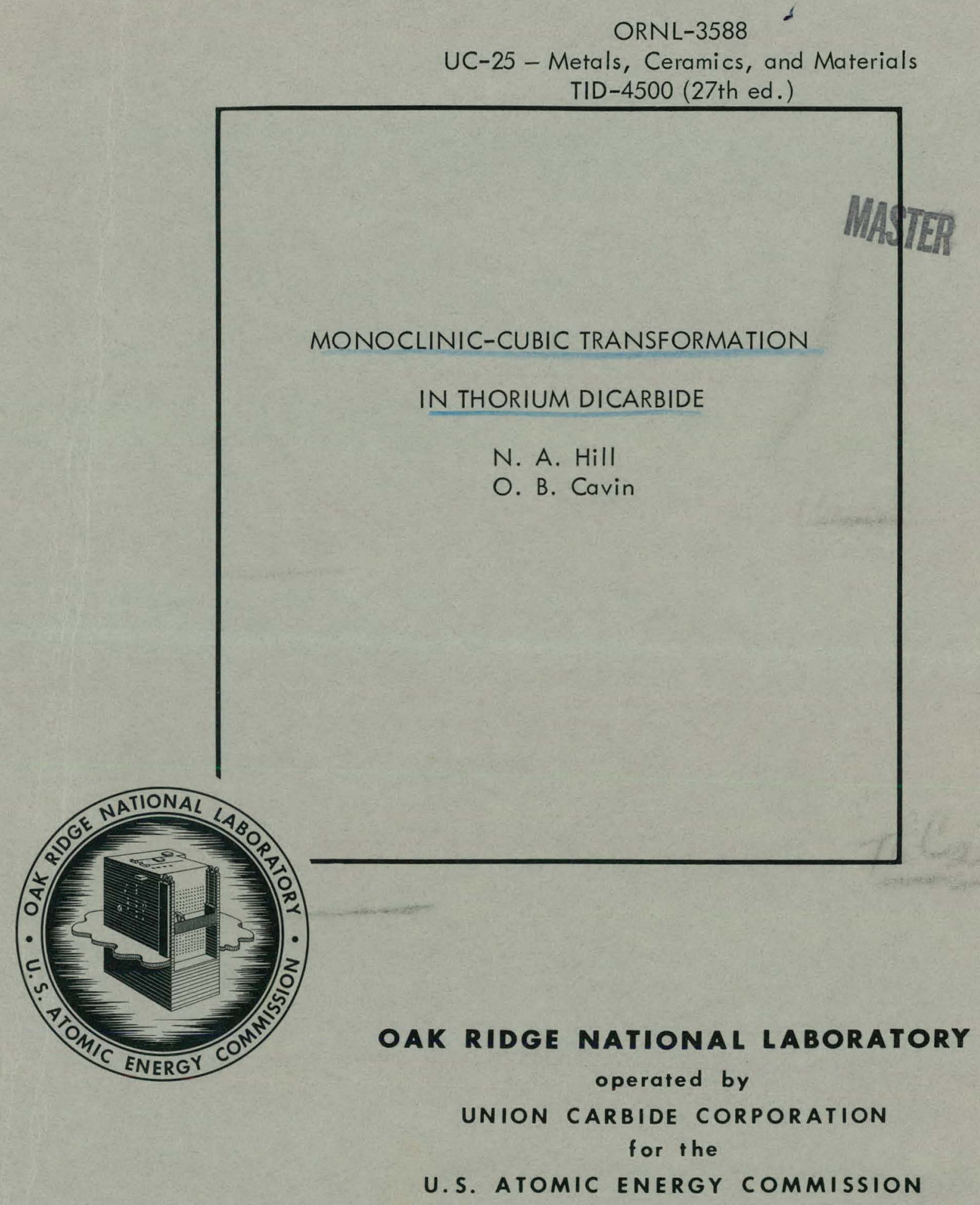




\section{DISCLAIMER}

This report was prepared as an account of work sponsored by an agency of the United States Government. Neither the United States Government nor any agency Thereof, nor any of their employees, makes any warranty, express or implied, or assumes any legal liability or responsibility for the accuracy, completeness, or usefulness of any information, apparatus, product, or process disclosed, or represents that its use would not infringe privately owned rights. Reference herein to any specific commercial product, process, or service by trade name, trademark, manufacturer, or otherwise does not necessarily constitute or imply its endorsement, recommendation, or favoring by the United States Government or any agency thereof. The views and opinions of authors expressed herein do not necessarily state or reflect those of the United States Government or any agency thereof. 


\section{DISCLAIMER}

Portions of this document may be illegible in electronic image products. Images are produced from the best available original document. 
LEGAL NOTICE

This report was prepared as an account of Government sponsored work. Neither the United States, nor the Commission, nor any person acting on behalf of the Commission:

A. Makes any warranty or representation, expressed or implied, with respect to the accuracy, completeness, or usefulness of the information contained in this report, or that the use of any information, apparatus, method, or process disclosed in this report may not infringe privately owned rights; or

B. Assumes any liabilities with respect to the use of, or for damages resulting from the use of any information, apparatus, method, or process disclosed in this report.

As used in the above, "person acting on behalf of the Commission" includes any employee or contractor of the Commission, or emplayee of such contractor, to the extent that such employee or contractor of the Commission, or employee of such contractor prepares, disseminates, or provides access to, any information pursuant to his employment or contract with the Commission, or his emplayment with such contractor. 
ORNL-3588.

Contract No. W-7405-eng-26

METALS AND CERAMICS DIVISION

N. A. Hill and O. B. Cavin

APRIL 1964

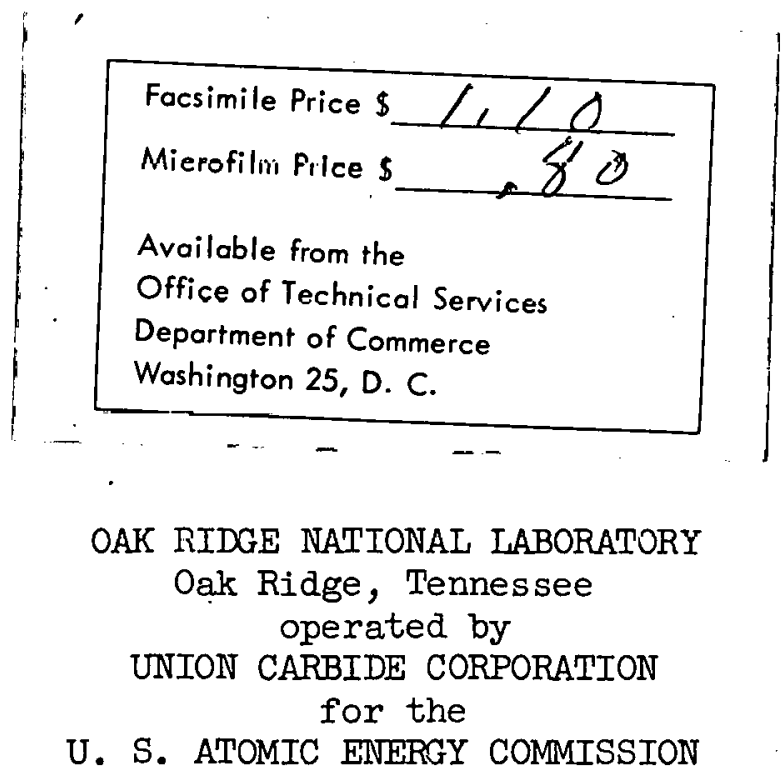


MONOCLINIC-CUBIC TRANSFORMATION IN THORIUM DICARBIDE

N. A. Hill ${ }^{2}$ and O. B. Cavin

Abstract

Thorium dicarbide has been found to transform at 1415 $\pm 10^{\circ} \mathrm{C}$ from the low-temperature monoclinic structure to a face-centered cubic structure with $\mathrm{a}_{0}=5.808 \pm 0.003 \mathrm{~A}$ at $1500^{\circ} \mathrm{C}$. It has not been possible to retain the hightemperature structure by quenching.

Introduction

Fissile-fertile nuclear fuels containing thorium-rich thoriumuranium dicarbide are of interest for use in graphite-base, hightemperature reactors. In connection with a study of the phase relations in this system, the crystal structure of thorium dicarbide was investigated as a function of temperature.

Arrests in heating and cooling curves of thorium dicarbide at 1430 and $1480^{\circ} \mathrm{C}$ have been reported by Langer, ${ }^{2}$ and Accary $^{3}$ has reported a marked change in thermal expansion at $1230-1300^{\circ} \mathrm{C}$.

In this paper, the results of $x$-ray diffraction from thorium dicarbide with excess graphite at temperatures up to $1700^{\circ} \mathrm{C}$ and the results of differential thermal analysis (DTA) up to $1500^{\circ} \mathrm{C}$ are presented.

Experimental Method

\section{High-Temperature X-Ray Diffraction}

Arc-melted thorium dicarbide (analysis in Table l) was crushed to powder under argon and mixed with graphite powder and dry kerosene. A

${ }^{1}$ A.F.R.F., Harwell, England, presently assigned to ORNL.

${ }^{2} \mathrm{~S}$. Langer, Physicochemical Properties of Carbides for Nhuclear Applications - A Review, GA-4450 (1963).

${ }^{3}$ Private communication. 
Table 1. Chemical Analysis of Thorium Dicarbide

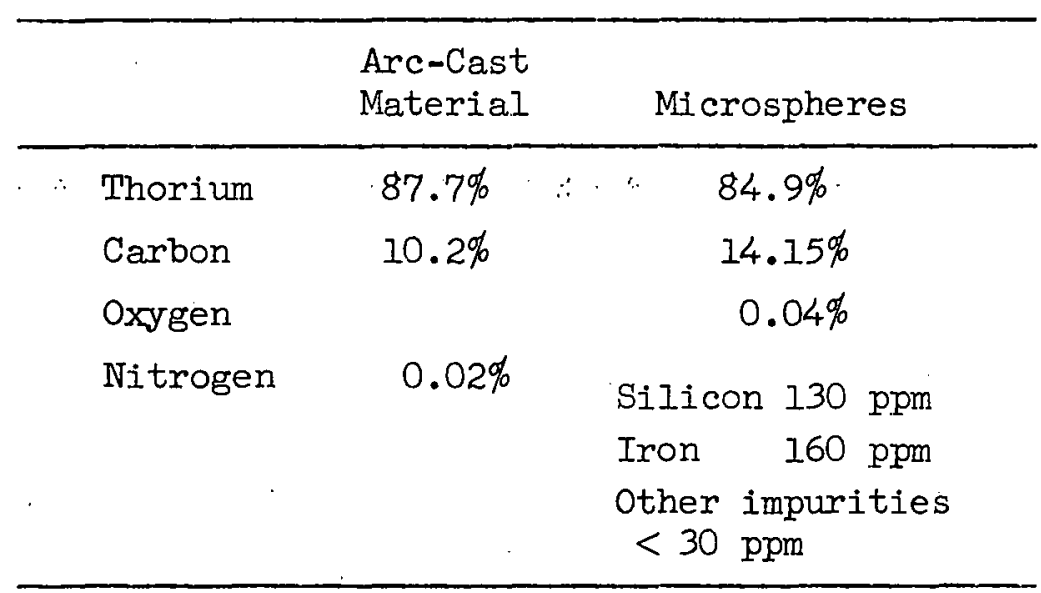

few drops of this slurry were placed on the tantalum strip heater in an "M.R.C." high-temperature $\mathrm{x}$-ray diffraction camera ${ }^{4}$ Model X-86-N mounted on a "Norelco" $x$-ray diffractometer. The camera was evacuated to $4 \times 10^{-5}$ torr and the specimen scanned from $2 \theta=22$ to $60^{\circ}$ at room temperature.

The tantalum strip and carbide specimen were heated slowly until the kerosene distilled off, then heated rapidly to $1200^{\circ} \mathrm{C}$. Diffractometer scans were obtained at $1200^{\circ} \mathrm{C}$, at $100^{\circ} \mathrm{C}$ intervals up to the maximum strip temperature $\left(2000^{\circ} \mathrm{C}\right)$, and back to $1200^{\circ} \mathrm{C}$. This heating and cooling cycle was repeated three times, and finally the strip was cooled to room temperature and the specimen scanned once more.

Temperatures were measured with a "Pyro" micro-optical, disappearingfilament pyrometer which could be:focused on the heating.strip or on . different areas of the specimen.

\section{Differential Thermal Analysis}

Thorium dicarbide microspheres (200- $\mu$ diam) (analysis in Table 1) were coated with a $10-\mu$ shell of pyrolytic carbon to reduce oxidation and loaded into one of the platinum buckets of a "Stone" DTA apparatus. The

${ }^{4}$ D. K. Smith, "Techniques of High-Temperature X-Ray Diffraction Using Metal Ribbon Furnaces," Norelco Rept. 10(1), 19 (1963). 
other platinum bucket was filled with powdered alumina as a standard. The chamber containing the specimen, standard, and furnace was evacuated to $10^{-2}$ torr and backfilled with argon several times.

Under argon at 1-atm pressure, the specimen and the alumina standard were heated at $10^{\circ} \mathrm{C} / \mathrm{min}$ to $1500^{\circ} \mathrm{C}$ and cooled at the same rate. The difference in output between thermocouples in contact with the two platinum buckets was recorded, and any transformation which absorbed or emitted heat produced a peak in the curve of differential output vs time: The temperature of the sample was recorded from a separate thermocouple.

Results

\section{$\underline{\text { X-Ray Diffraction }}$}

The initial room-temperature trace showed peaks from graphite, monoclinic thorium dicarbide, and a little thorium dioxide. At a surface temperature of $1200^{\circ} \mathrm{C}$, the specimen gave the same peaks (slightly displaced by thermal expansion); but at $1300^{\circ} \mathrm{C}$ surface temperature $\left(1500^{\circ} \mathrm{C}\right.$ maximum within the specimen as discussed below), a new set of lines appeared, corresponding to a face-centered cubic lattice and quite distinct from the thorium oxide lines. At a surface temperature of $1500^{\circ} \mathrm{C}$, the monoclinic thorium dicarbide lines had disappeared, leaving graphite lines, weak thorium dioxide lines, and strong lines frow the new face-centered cubic material. To correct for any shift in $2 \theta$ from misalignment of the specimen or the $x$-ray beam, the thorium dioxide lines were used as standards for the adjacent new face-centered cubic lines. The corrected values are given in Tulule 2 . Ovcr the range $2 A=26-54^{\circ}$, the unit cell edges calculated from each diffraction line are in very close agreement, giving

$$
a_{0}=5.808 \pm 0.003 \mathrm{~A}\left(\text { at } 1500^{\circ} \mathrm{C}\right)
$$

for the new face-centered cubic thorium dicarbide phase. No higher $2 \partial$ values were obtainable so it was not possible to apply any systematic correction, but the consistency of better than $\pm 0.1 \%$ shown in Table 2 over the range $2 \theta=26-54^{\circ}$ indicates that this data should give a reliable and accurate lattice parameter value. 
Table 2. High-Temperature X-Ray Diffraction Results from Arc-Cast Thorium Dicarbide at $1500^{\circ} \mathrm{C}$

( $\mathrm{CuK}_{\alpha}$ radiation: $\lambda=1.54178 \mathrm{~A}$ )

\begin{tabular}{cccc}
$\begin{array}{c}2 \theta \\
(\mathrm{deg})\end{array}$ & $\begin{array}{c}\mathrm{d} \\
(\mathrm{A})\end{array}$ & $\begin{array}{c}\mathrm{a}_{\mathrm{o}} \\
(\mathrm{A})\end{array}$ & $\mathrm{I} / \mathrm{I}_{\mathrm{o}}$ \\
\hline 26.57 & 3.355 & 5.811 & 100 \\
30.78 & 2.905 & 5.810 & 80 \\
44.08 & 2.054 & 5.810 & 50 \\
52.25 & 1.750 & 5.804 & 40 \\
54.76 & 1.676 & 5.806 & 10 \\
$\begin{array}{c}\text { Average a } \\
\text { face-centered cubic. }\end{array}$ & & \\
\hline
\end{tabular}

On holding the specimen at a surface temperature of $1600^{\circ} \mathrm{C}$, the thorium oxide lines weakened and eventually disappeared, leaving graphite and the new face-centered cubic thorium dicarbide lines.

There was no evidence for any further transformation on heating to the maximum temperature of approximately $1700-1800^{\circ} \mathrm{C}$ in the center of the specimen. The thorium dicarbide was cycled three times between surface temperatures of 1100 and $1600^{\circ} \mathrm{C}$, and each time the monocliniccubic-monoclinic transformations occurred, confirming that the transformation is reversible. Comparison of the diffractometer traces of the face-centered cubic thorium dicarbide in the presence and the absence of thorium dioxide showed no detectable difference, indicating that there is no major solubility of oxygen in this structure. Once the oxide had transformed to carbide at high temperatures, it did not reappear during subsequent cycling.

Throughout the work, a marked temperature gradient existed in the specimen. When the tantalum strip was at $2000^{\circ} \mathrm{C}$, the adjacent layers of the specimen were at approximately $1800^{\circ} \mathrm{C}$ and the surface at $1600-1700^{\circ} \mathrm{C}$. It was not possible, therefore, to measure the transformation temperature although the temperatures at which the transformation began and ended during heating and cooling could be estimated as 1390 and $1440^{\circ} \mathrm{C}$, respectively. As there were large temperature differences within the specimen, no emissivity or absorption corrections were applied to the temperature measurements. 


\section{Differential Thermal Analysis}

On heating the pyrolytic carbon-coated thorium dicarbide spheres, a peak due to a transformation began at $1425^{\circ} \mathrm{C}$; on cooling, a similar peak in the reverse direction began at $1405^{\circ} \mathrm{C}$, indicating a transformation temperature of $1415 \pm 10^{\circ} \mathrm{C}$. The heating and cooling rates were both $10^{\circ} \mathrm{C} / \mathrm{min}$; and, as shown in the trace reproduced in $\mathrm{Fig}$. I, the peaks are virtually identical in size and shape.

In some of the early runs before the argon atmosphere was dried, a large peak occurred at $1470-1500^{\circ} \mathrm{C}$; subsequent peaks at $1415^{\circ} \mathrm{C}$ were smaller and finally disappeared. These samples showed mainly thorium oxide on $x$-ray diffraction analysis after the DIA runs were completed. This indicates that the large peak observed is in some way connected with the oxidation of the particles, and the diminution of the peak at $1415^{\circ} \mathrm{C}$ was due to a proportion of the thorium carbide being oxidized.

\section{Discussion}

From the results, it is evident that above approximately $1400^{\circ} \mathrm{C}$ thorium dicarbide has a face-centered cubic structure with $a_{0}=5.808 \pm 0.003 \mathrm{~A}$ (at $1500^{\circ} \mathrm{C}$ ); and, since DTA results show a reversible structure change in thorium dicarbide particles (coated with pyrolytic carbon) at $1415 \pm 10^{\circ} \mathrm{C}$, it seems most likely that the reversible monoclinic-cubic transformation causes this peak. Hence it is concluded that the cubic phase is the stable phase in thorium dicarbide above $1415 \pm 10^{\circ} \mathrm{C}$, and no other transformation occurs in the presence of excess graphite up to $1700^{\circ} \mathrm{C}$ (the upper temperature limit of the $\mathrm{x}$-ray diffraction runs).

In the low-temperature monoclinic thorium dicarbide, Hunt and Rundle ${ }^{5}$ concluded that the carbon atoms are arranged in pairs. In the present work, attempts to retain the high-temperature cubic form by quenching failed, indicating that the cubic-monoclinic transformation is very rapid and may be diffusionless as suggested by chang ${ }^{6}$ for the

${ }^{5}$ E. B. Hunt and R. E. Rundle, "The Structure of Thorium Dicarbide by X-Ray and Neutron Diffraction," J. Amer. Chem. Soc. 73 , 4777 (1951).

${ }^{6} \mathrm{R}$. Chang, "A Diffusionless $\mathrm{UC}_{2}$ (Cubic) to $\mathrm{UC}_{2}$ (Tetragonal) I'ranstormation," Acta Cryst. 14, 1097 (1961). 


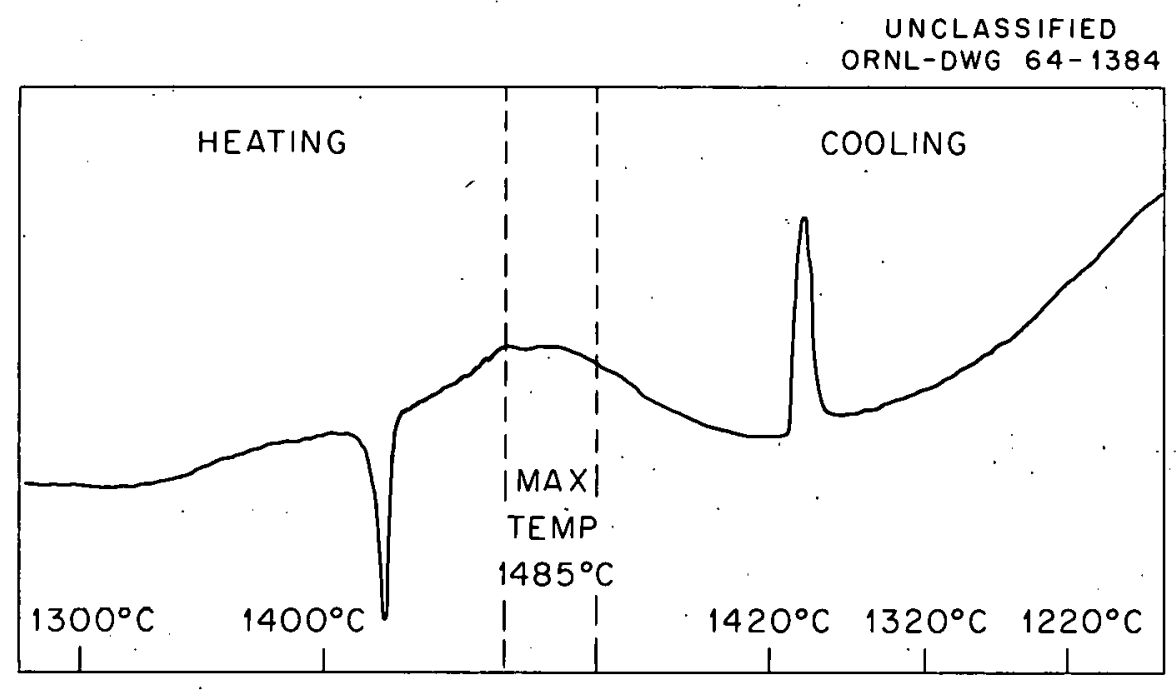

Fig. 1. Differential Thermal Analysis Trace from Thorium Dicarbide Showing Transformation Peaks on Heating and Cooling. 
cubic-tetragonal $\mathrm{UC}_{2}$ transformation. In this case, provided the paired carbon groups in monoclinic thorium dicarbide exist at $1400^{\circ} \mathrm{C}$, it is likely that the high-temperature cubic structure also contains these groups.

Metallography of arc-cast thorium dicarbide shows that there is marked twinning visible under polarized light as shown in Fig. 2. These twins may well be formed by the cubic-monoclinic transformation on cooling from the melting temperature. There is no evidence of fine graphite or other precipitate within the grains, indicating that there is no marked change in stoichiometry associated with the phase transformation; all the excess graphite is in the form of massive stringers.

\section{Conclusions}

High-temperature $\mathrm{x}$-ray diffraction results showed that thorium dicarbide has a face-centered cubic structure with $a_{0}=5.808 \pm 0.003 \mathrm{~A}$ at $1500^{\circ} \mathrm{C}$. Differential thermal analysis of thorium dicarbide showed a peak both on heating and on cooling at $1415 \pm 10^{\circ} \mathrm{C}$, corresponding to the reversible monoclinic-cubic transformation observed by $\mathrm{x}$-ray diffraction. No cubic structure was retained on quenching to room temperature, indicating a diffusionless transformation which may cause the twins observed in the microstructure of thorium dicarbide.

\section{Acknowledgments}

R. E. MacDonald provided the arc-melted material; G. B. Marrow provided the microspheres which were coated by R. L. Beatty; the metallography was directed by R. J. Gray. W. O. Harms and H. L. Yakel gave advice and encouragement throughout the work. 


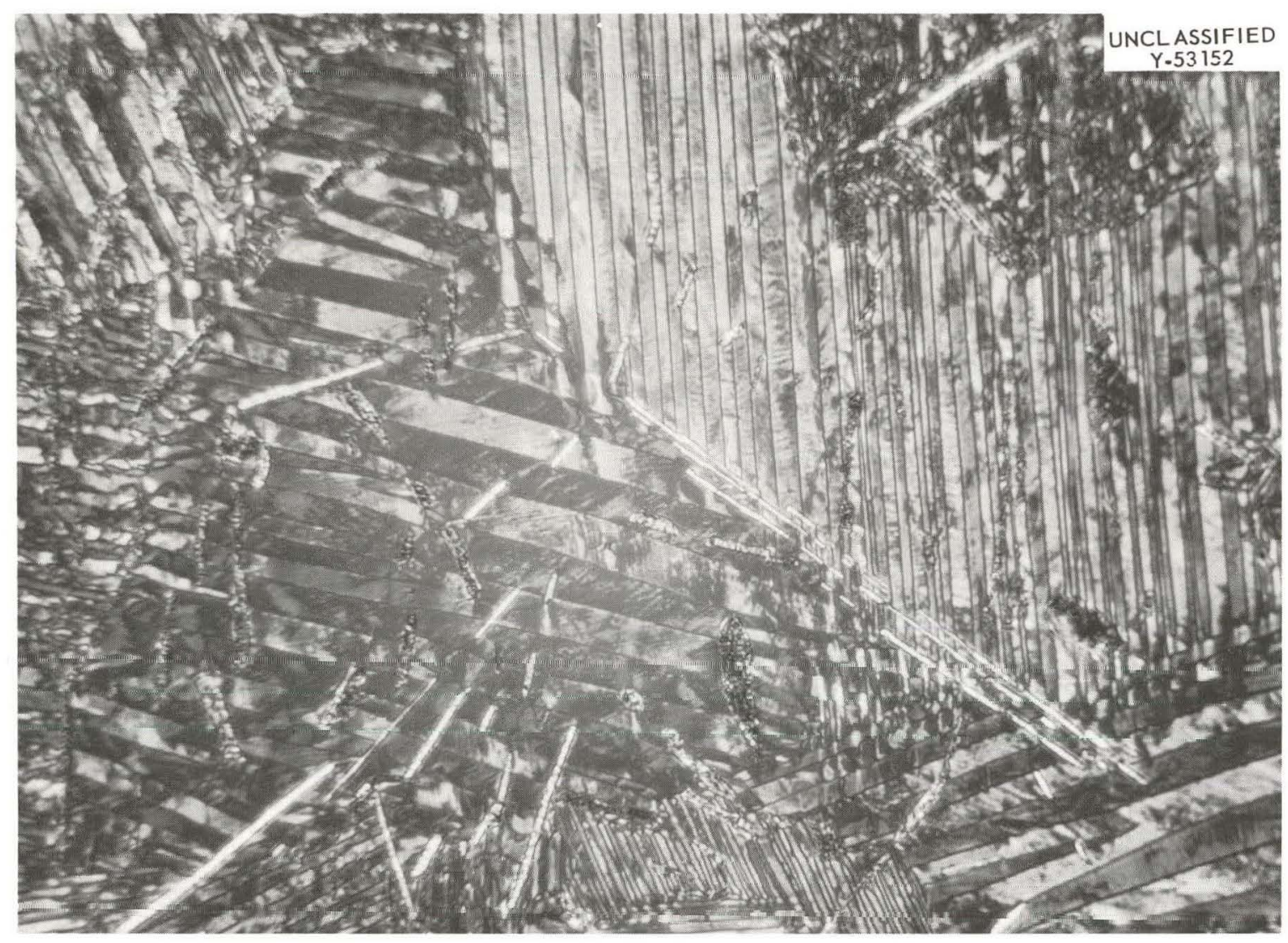

Fig. 2. Microstructure of Thorium Dicarbide under Polarized Light Showing Extensive Twinning and Massive Stringers of Graphite. 1000X. 
ORNL-3588

UC-25 - Metals, Ceramics, and Materials TID-4500 (27th ed.)

\section{INTERNAL DISTRIBUTION}

1-3. Central Research Library

4. Reactor Division Library

5-6. ORNL - Y-12 Technical Library

Document Reference Section

7-16. Laboratory Records Department

17. Laboratory Records, ORNL RC

18. ORNL Patent Office

19. R. E. Adams

20. F. I. Carlsen, Jr.

21-28. 0. B. Cavin

29. T. F. Connolly

30. J. H. Coobs

31. J. L. Cook

32. J. E. Cunningham

33. O. C. Dean

34. J. H Frye, Jr.

35. L. O. Gilpatrick

36. T. G. Godfrey

37. R. J. Gray
38. W. R. Grimes

39. W. O. Harms

40-44. M. R. Hill

45-55. N. A. Hill

56. T. M. Kegley, Jr.

57. C. E. Larson

58. A. L. Lotts

59. H. G. MacPherson

60-124. W. D. Manly

125. J. L. Scott

126. J. A. Swartout

127. S. A. Rabin

128. R. M. Steele

129. R. E. Thoma

130. A. M. Weinberg

131. A. A. Burr (consultant)

132. J. R. Johnson (consultant)

133. C. S. Smith (consultant)

134. R. Smoluchowski (consultant)

EXTERNAL DISTRIBUTION

135. A. Accary, CEA, Saclay

136. C. M. Adams, Jr., MIT

137. D. E. Baker, GE Hanford

138-139. D. F. Cope, ORO

140. Ersel Evans, GE Hanford

141. G. M. Farrior, US Bureau of Mines, Norris

142. J. I. Cregg, Connell University

143. J. Henney, AERE, Harwell

144. G. H. Horsley, AEE, Winfrith

145. R. A. V. Huddle, AEE, Winfrith

146. J. W. G. Jones, AERE, Harwell 157-653.

147. S. Lanzer, General Atomics

148. D. T. Livey, AERE, Harwell

149. P. Murray, AERE, Harwell
150. Research and Development, ORO

151. L. E. J. Russell, AERE, Harwell

152. J. B. Sayers, AERE, Harwell

153. J. Simmons, AEC, Washington

154. E. E. Stansbury, University of Tennessee

155. D. K. Stevens, AEC, Washington

J. Williams, AERE, Harwell

Given distribution as shown in TID-4500 (27th ed.) under Metals, Ceramics, and Materials category 